\title{
Analisis Properti Psikometri Career Adapt-Ability Scale pada Siswa Sekolah Menengah Kejuruan (SMK)
}

\author{
Nyayu Nazihah Khairunnisa, Anissa Lestari Kadiyono, Witriani \\ Program Studi Psikologi, Fakultas Psikologi, Univeristas Padjadjaran, Bandung
}

Abstrak. Sebagai dampak dari perkembangan dunia kerja yang semakin fleksibel, individu dituntut untuk memiliki kemampuan adaptasi dalam konteks karier yang disebut dengan career adaptability. Career Adapt-Ability Scale (CAAS) merupakan alat ukur yang disusun oleh Savickas dan Porfeli ditujukan untuk mengukur career adaptability. Penelitian ini bertujuan untuk mengevaluasi properti psikometri Career Adapt-Ability Scale yang telah diadaptasi ke bahasa Indonesia. Responden penelitian ini berjumlah 121 orang dengan rentang usia $14-17$ tahun. Penelitian ini dibagi ke dalam dua tahapan: Pertama, melakukan estimasi reliabilitas melalui internal consistency dengan mengevaluasi nilai koefisien Alpha Cronbach dan melalui analisis item discrimination dengan mengevaluasi nilai corrected-item total correlation pada masingmasing butir. Hasilnya menunjukkan bahwa alat ukur CAAS dapat diandalkan dan memiliki reliabilitas yang baik $(\alpha=.746-$.923). Kedua, menguji validitas konstruk menggunakan confirmatory factor analysis, hasilnya menunjukkan bahwa data yang ada sesuai dengan model teori career adaptability dan setiap butir pada alat ukur CAAS terbukti signifikan dalam mengukur dimensinya pada konstruk career adaptability. Dengan demikian, disimpulkan bahwa alat ukur CAAS ini dapat diandalkan untuk mengukur career adaptability.

Kata Kunci: career adaptability, career adapt-ability scale, reliabilitas, validitas konstruk

\section{Psychometric Properties Analysis of Career Adapt-Ability Scale on Vocational High School Students}

\begin{abstract}
The increasingly changes in the world of work require individual to have the ability to adapt in a career context called career adaptability. The Career Adapt-Ability Scale (CAAS) is a measuring tool developed by Savickas and Porfeli aimed at measuring career adaptability. This study aims to evaluate the psychometric properties of the Career Adapt-Ability Scale which has been adapted to Bahasa. The subjects of this study were 121 students at vocational schools aged 14-17 years old. This study was divided into two stages: First, conducting a reliability test through internal consistency by evaluating the coefficient value of Cronbach's alpha and through item discrimination analysis by evaluating the value of the corrected-item total correlation on each item. The results show that the CAAS measuring instrument has good reliability ( $\alpha=.746$ .923). Second, testing the validity construct using confirmatory factor analysis, the results show that the data is in accordance with the career adaptability theory model and each item on the CAAS measuring instrument is proven significant in measuring its dimensions in the career adaptability construct. Thus, it is concluded that the CAAS measuring instrument can be relied upon to measure career adaptability.
\end{abstract}

Keywords: career adaptability, Career Adapt-ability Scale, construct validity, reliability

Korespondensi: Nyayu Nazihah Khairunnisa. Email: nyayunazihahk@gmail.com 
Dunia kerja saat ini mengalami perubahan yang cukup signifikan. Salah satu faktor yang mengubah dunia kerja secara signifikan adalah perkembangan teknologi industri dan informasi. Dampak dari perkembangan teknologi industri dan informasi adalah hilangnya lapangan-lapangan pekerjaan dan munculnya lapangan-lapangan pekerjaan yang baru. Selain itu, faktor yang juga mengubah dunia kerja secara signifikan adalah perubahan atau kesulitan ekonomi global yang dialami saat ini. Dampak yang terjadi dari timbulnya perubahan atau kesulitan ekonomi ini adalah banyak individu mengalami stress serta kekhawatiran kehilangan pekerjaan. Keadaan pasar tenaga kerja saat ini merubah konsep karier dengan cukup signifikan. Karier saat ini menjadi lebih luas, global, dan tidak terbatas serta menuntut fleksibilitas yang tinggi. Dengan demikian, individu membutuhkan kemampuan beradaptasi untuk dapat mengembangkan kariernya pada saat ini maupun di masa yang akan datang. Kemampuan beradaptasi dalam konteks karier ini disebut dengan career adaptability.

\section{Career adaptability merupakan} perspektif perkembangan karier dan strategi coping yang menjelaskan tentang bagaimana individu melakukan proses adaptasi karier (Savickas \& Porfeli, 2005). Career adaptability adalah attitudes, competencies, dan behavior yang digunakan individu dalam menyesuaikan diri dengan pekerjaan yang cocok dengan mereka (Savickas \& Porfeli, 2005). Career adaptability merupakan sumber daya (resources) psikososial individu untuk menghadapi tugas perkembangan karier, transisi pekerjaan, dan trauma kerja yang dialami saat ini maupun yang diantisipasi di kemudian hari (Savickas \& Porfeli, 2005). Individu menggunakan self-regulatory resources ini untuk mengatasi masalah yang unfamiliar, kompleks, dan sulit dijelaskan dalam tugas-tugas, transisi, dan trauma kerja. Resources ini disebut psikososial karena berupa persimpangan person-in-environment.

Career construction theory mendefinisikan empat dimensi global dari career adaptability dan mengelompokkan mereka ke dalam model struktural dengan 3 tingkatan atau level. Pada tingkatan tertinggi dan paling abstrak terdapat 4 dimensi dari career adaptability: concern, control, curiosity, dan confidence. Keempat dimensi ini merepresentasikan strategi dan sumber daya adaptabilitas secara umum yang digunakan individu untuk mengatur tugas perkembangan karier, transisi, dan trauma kerja saat mereka membangun karier.

Pada tingkat menengah, model ini menggambarkan serangkaian variabel homogen dengan fungsi yang berbeda untuk masing-masing dari empat dimensi umum. Masing-masing dari variabel tengah atau perantara ini meliputi sikap (attitudes), kepercayaan (belief), dan kompetensi (competencies) spesifik (ABC dari career construction) yang membentuk perilaku 
adaptasi konkret dan digunakan untuk menguasai tugas perkembangan, menegosiasikan transisi pekerjaan, dan menyelesaikan trauma kerja. Sikap (attitudes) adalah variabel afektif atau perasaan yang memicu perilaku, sedangkan keyakinan (belief) adalah variabel konatif atau inklusif yang mengarahkan perilaku. Attitudes dan beliefs ini mendorong individu untuk bertindak dengan cara tertentu, dan dengan demikian mereka membentuk kecenderungan respon terhadap lingkungan. Kompetensi (competencies), termasuk pemahaman dan kemampuan memecahkan masalah yang menunjukkan sumber daya kognitif untuk membuat dan menerapkan pilihan karier. Attitude dan belief yang dimiliki individu membentuk perkembangan dan penggunaan kompetensi. Pada akhirnya, cognitive competencies ini membentuk perilaku beradaptasi yang benarbenar menghasilkan perkembangan karier.

Coping behaviors ini merupakan tingkat ketiga dan paling konkret dalam model struktural career adaptability. Vocational behavior menunjukkan banyaknya coping behaviors yang menghasilkan vocational development dan membangun karier. Kolom terakhir pada Tabel 1 di bawah ini mencantumkan kemungkinan masalah karier yang akan terjadi jika masing-masing adaptability resources kurang berkembang dengan optimal.

Tabel 1

Model Struktural Career Adaptability

\begin{tabular}{|c|c|c|c|c|}
\hline $\begin{array}{c}\text { Adaptability } \\
\text { Dimension }\end{array}$ & $\begin{array}{c}\text { Attitudes and } \\
\text { Beliefs }\end{array}$ & Competence & $\begin{array}{c}\text { Coping } \\
\text { Behaviors }\end{array}$ & $\begin{array}{r}\text { Ca } \\
\text { Pro }\end{array}$ \\
\hline Concern & Planful & Planning & $\begin{array}{l}\text { Aware } \\
\text { Involved } \\
\text { Preparing }\end{array}$ & Indiffer \\
\hline Control & Decisive & $\begin{array}{l}\text { Decision } \\
\text { Making }\end{array}$ & $\begin{array}{l}\text { Assertive } \\
\text { Disciplined } \\
\text { Willful }\end{array}$ & Indecis \\
\hline Curiosity & Inquisitive & Exploring & $\begin{array}{l}\text { Experimenting } \\
\text { Risk taking } \\
\text { Inquiring }\end{array}$ & Unreali $_{i}$ \\
\hline Confidence & Efficacious & $\begin{array}{l}\text { Problem } \\
\text { Solving }\end{array}$ & $\begin{array}{l}\text { Persistent } \\
\text { Striving } \\
\text { Industrious }\end{array}$ & Inhibiti $_{i}$ \\
\hline
\end{tabular}

Catatan. Sumber penjelasan singkat dari "Career Adapt-Abilities Scale: Construction, reliability, and measurement equivalence across 13 countries" ditulis oleh Savickas, M. L., dan Porfeli, E. J., 2012, 80(3). 
Alat ukur CAAS untuk menggambarkan career adaptability resources yang dimiliki oleh individu disusun oleh Savickas dan Porfeli (2012). Menurut Savickas dan Porfeli (2012) adaptabilitas dilihat sebegai resources atau sumber daya psikososial atau transactional competencies lebih dapat diubah daripada traits. Adaptability resources ini membentuk strategi yang digunakan individu untuk mengarahkan perilaku adaptif mereka dalam memenuhi tuntutan-tuntutan di lingkungan. Dengan demikian, career adaptability resources perlu dipandang sebagai kompetensi psikososial yang membentuk strategi dan perilaku adaptif untuk mencapai tujuan adaptasi (Savickas \& Porfeli, 2012).

CAAS merupakan alat ukur pertama yang dikembangkan oleh Savickas sebagai penggagas utama teori career adaptability. Savickas berupaya menyusun dan menggabungkan empat dimensi untuk menggambarkan konstruk career adaptability. Penelitian Hamtiaux et al (2013) menjelaskan bahwa konsep adaptability telah muncul dan pengukurannya sudah dikembangkan terlebih dahulu oleh Ployhart dan Bliese (2006), yaitu individual adaptability (IA). IA melihat kemampuan adaptability yang dimiliki individu secara umum, tidak spesifik terhadap situasi atau konteks tertentu, sedangkan Savickas mengembangkan konstruk adaptability yang spesifik pada konsep pembentukan karier (Hamtiaux et al, 2013). Oleh karena itu, peneliti tertarik untuk mengadaptasi CAAS yang langsung dikembangkan oleh Savickas sebagai penggagas career construction theory.

Studi yang dilakukan dengan kolaborasi 13 negara telah menghasilkan pengukuran career adaptability yang valid (Savickas \& Porfeli, 2012). Hasil menunjukkan bahwa CAAS mengukur konstruk yang sama dengan cara yang sama di seluruh negara. Di Indonesia, Sulistiani et al (2018) melakukan penelitian mengenai adaptasi alat ukur CAAS versi bahasa Indonesia dengan populasi mahasiswa di suatu universitas di Surabaya, Indonesia. Hasilnya menunjukkan bahwa CAAS-Indonesian Forms yang dikembangkan valid untuk mengukur career adaptability (Sulistiani et al., 2018). Walau demikian, konstruk psikososial—seperti adaptability-sangat sensitif terhadap konteks dan usia (Savickas \& Porfeli, 2012). Perbedaan negara, status ekonomi, dan budaya dapat memunculkan perbedaan pada kesempatan mengembangkan adaptability (Savickas \& Porfeli, 2012). Oleh karena itu, pengembangan atau adaptasi alat ukur CAAS pada berbagai latar belakang negara dan budaya dibutuhkan untuk mengukur adaptabillity yang sesuai dengan kondisi negara tertentu. Dalam penelitian ini, peneliti bermaksud untuk mengadaptasi alat ukur CAAS dan mengumpulkan bukti validitas dan reliabilitas dengan populasi salah satu sekolah di Jawa Barat, Indonesia.

Dalam melakukan penelitian, penting bagi peneliti untuk memastikan alat ukur yang digunakan sudah tepat mengukur hal yang ingin diukur. Dua cara yang dilakukan peneliti dalam 
memastikan hal ini melalui reliabilitas dan validitas. Reliabilitas merupakan konsistensi, stabilitas, dan pengulangan dari suatu perilaku (Christensen et al., 2015). Suatu alat ukur dapat dikatakan reliabel jika butir pada alat ukur tersebut akan tetap mengukur konstruk yang sama (hasil yang didapatkan sama) walaupun diukur pada responden yang berbeda dan pada waktu yang berbeda pula (Goodwin, 2010). Penelitian Kaplan dan Saccuzzo (2009) menyatakan bahwa sekumpulan pernyataan yang mengukur suatu variabel dinyatakan reliable (dapat diandalkan) jika koefisian reliabilitasnya lebih dari atau sama dengan .700 . Suatu alat ukur dikatakan valid jika butir-butir yang menyusun alat ukur tersebut benar dan dapat mengukur konstruk yang akan diukur (Goodwin, 2010). Validitas alat ukur dapat diuji dengan mengumpulkan bukti-bukti validitas. Menurut Kaplan dan Saccuzzo (2009) buktibukti validitas ini terbagi menjadi empat, yaitu face validity, content-related evidence for validity, criterion-related evidence for validity, dan construct related evidence for validity.

Pada penelitian Liman (2018) telah melakukan dengan adaptasi alat ukur CAAS ini dengan sampel siswa SMK di Kota X. Pengambilan data uji coba untuk melihat reliabilitas alat ukur dilakukan kepada 42 responden siswa SMK populasi penelitian Liman (2018). Hasil estimasi reliabilitas menunjukkan nilai alpha cronbach's sebesar .893. Berdasarkan kriteria Kaplan dan Saccuzzo (2009) yang menyatakan alat ukur dikatakan reliabel jika memiliki nilai reliabilitas sebesar z.70, maka alat ukur adaptasi Liman (2018) dinyatakan memiliki reliabilitas yang baik.

Selain itu, Liman (2018) mengumpulkan bukti validitas berupa validity evidence on response process dengan cara interview terkait butir-butir penyusun alat ukur kepada 10 responden. Berdasarkan Standars for Educational and Psychological Testing (Liman, 2018) validity based on response process adalah suatu bentuk pengumpulan bukti mengenai kesesuaian antara konstruk dengan respon yang diberikan individu terhadap konstruk tersebut atau kesesuaian antara konstruk dengan hal yang mendasari individu memberikan respon terhadap konstruk (proses kognitif yang terjadi selama individu memberikan jawaban pada setiap butir tes). Bukti ini didapatkan dengan cara menanyakan respon individu pada setiap butir alat ukur atau menanyakan individu mengenai landasan berespon. Setelah dilakukan proses interview, Liman (2018) melakukan pengolahan data secara kualitatif pada seluruh respon yang diberikan responden. Dari hasil pengolahan data Liman (2018) melakukan penyesuaian diksi dan makna dari setiap butir pada alat ukur adaptasi agar dapat dimengerti oleh responden. Terdapat 19 butir adaptasi yang diubah oleh Liman (2018) terkait pilihan kata pada butir agar dapat lebih mudah dimengerti oleh responden.

Pengumpulan bukti validitas yang dilakukan oleh Liman (2018) berupa evidence 
based on test content dengan cara expert review. Expert review dilakukan untuk melihat kesesuaian butir dari alat ukur dengan konstruk yang diukur, yakni career adaptability. Dari hasil expert review, terdapat 4 butir yang kurang memadai dan perlu dilakukan perubahan kembali agar memiliki kesesuaian isi seperti alat ukur asli sehingga dapat lebih akurat mengukur konstruk career adaptability. Setelah dilakukan perubahan, melakukan uji coba kepada 42 siswa-siswi SMK populasi penelitiannya.

Dalam penelitian ini, peneliti bermaksud melakukan estimasi reliabilitas untuk melihat hasil reliabilitas alat ukur ini pada populasi yang lain dan mengumpulkan bukti validitas konstruk menggunakan confirmatory factor analysis (CFA). CFA digunakan untuk melihat apakah alat ukur yang dibuat sesuai dengan teori yang digunakan dengan melihat korespondensi antara indikator dan konstruknya (Hair et al., 2014). Dalam penelitian ini, CFA dilakukan untuk membuktikan apakah masing-masing butir atau indikator mengukur empat dimensi career adaptability, yaitu concern, control, curiosity, dan confidence, serta membuktikan apakah keempat dimensi ini merepresentasikan konstruk career adaptability pada konteks negara dan budaya Indonesia. Dengan demikian, CFA dapat menunjukkan apakah adaptasi alat ukur CAAS ini dapat digunakan untuk mengukur career adaptability pada konteks negara dan budaya Indonesia.

\section{Metode}

Responden penelitian ini berjumlah 121 orang siswa kelas X di salah satu SMK di Jatinangor dengan rentang usia 14 - 17 tahun yang bersedia mengisi kuesioner alat ukur online melalui Google Form. Teknik yang digunakan pada penelitian ini adalah nonprobability sampling dengan metode snowball sampling. Peneliti melakukan penyebaran kuesioner secara online melalui Google Form kepada perwakilan siswa dari beberapa kelas X SMK di Jatinangor. Perwakilan siswa ini kemudian menyebarkan link kuesioner pada group chat untuk diisi oleh siswa lain.

CAAS yang telah diadaptasi ke bahasa Indonesia terdiri dari 24 butir pernyataan. Masing-masing dimensi terdiri dari 6 butir pernyataan. Keseluruhan soal merupakan pernyataan positif. Skala yang digunakan adalah skala Likert dengan 5 kategori, yaitu (a) kurang kuat, (b) cukup kuat, (c) kuat, (d) sangat kuat dan (e) paling kuat. Cara mengisi kuesioner adalah memberikan penilaian seberapa kuat kelebihan atau kemampuan yang dimiliki oleh responden dengan memilih angka yang paling menggambarkan diri responden pada saat itu.

Dari hasil kuesioner yang didapat, peneliti melakukan estimasi reliabilitas melalui internal consistency dengan mengevaluasi nilai koefisien Alpha Cronbach dan melalui analisis item discrimination dengan mengevaluasi nilai corrected-item total correlation pada masingmasing butir. Menurut Kaplan \& Saccuzzo 
(2009), alat ukur dikatakan reliabel jika memiliki koefisien reliabilitas sebesar $\geq .70$. Selain itu, semakin besar nilai corrected itemtotal correlation pada masing-masing butir maka semakin tinggi daya beda butir. Artinya, masing-masing butir mengukur hal yang berbeda. Jika nilai corrected item-total correlation berada $<.30$ maka butir tersebut mengukur hal yang sama dengan butir lain sehingga perlu diperbaiki atau dihapus. Pengukuran reliabilitas dilakukan dengan bantuan software SPSS. Untuk mengumpulkan bukti validitas struktur internal alat ukur, dilakukan CFA dengan bantuan software LISREL. CFA digunakan untuk membandingkan kesesuaian antara model teoritik dengan data yang diperoleh. Kuesioner ini bersifat multidimensi oleh sebabnya dilakukan CFA dengan metode second order factor analysis.

Prosedur CFA diawali dengan melakukan first order factor analysis untuk menguji apakah setiap butir yang terdapat pada kuesioner telah merepresentasikan aspek/dimensi yang diukur. Hasil estimasi menggambarkan kesesuaian antara butir terhadap dimensinya. Setelah mendapatkan hasil estimasi yang sesuai dengan model, kemudian dilakukan ekstraksi skor variabel laten yang terdapat pada masingmasing aspek/dimensi yang diukur. Hasil ekstraksi skor variabel laten yang terdapat pada masing-masing aspek/dimensi kemudian digunakan sebagai data untuk melakukan second order analysis dengan menguji apakah aspek/dimensi tersebut merupakan elemenelemen yang relevan digunakan untuk mengestimasi suatu konstruk laten (Koufteros \& Marcoulides, 2006). Kriteria yang digunakan untuk melihat butir yang signifikan dalam mengukur faktornya adalah dengan nilai $t>$ 1.96. Terdapat dua metode yang digunakan untuk melihat seberapa baik suatu model secara menyeluruh yaitu Absolut Fit Measure dan Increment Fit Measure. Penjelasan lebih lanjut mengenai kedua pengukuran adalah sebagai berikut (Hair et al, 2014):

1) Absolut Fit Measure, yaitu cara pengukuran suatu model secara keseluruhan dengan beberapa kriteria antara lain nilai Chi-square, Goodness-of-fit index (GFI), dan Root Mean Square Error of Approximation (RMSEA).

2) Increment Fit Measure, yaitu cara pengukuran suatu model fit dengan membandingkan model yang diusulkan dengan model dasar (baseline model). Kriteria pengukuran ini adalah Normal Fit Index (NFI), Comparative Fit Index (CFI), dan Relative Fit Index (RFI).

Di bawah ini merupakan kriteria untuk masing-masing pengukuran untuk mengevaluasi validitas dengan proses confirmatory factor analysis: 


\section{Tabel 2}

Kriteria Goodness of Fit Indices

\begin{tabular}{lc}
\hline \multicolumn{1}{c}{ Estimasi } & Kriteria \\
\hline Minimum Fit Function Chi-Square & $p>.05$ \\
\hline Root Mean Square Error of Approximation (RMSEA) & $<.08$ \\
\hline Goodness of Fit Index (GFI) & $\geq .90$ \\
\hline Normed Fit Index (NFI) & $\geq .90$ \\
\hline Comparative Fit Index (CFI) & $\geq .90$ \\
\hline Relative Fit Index (RFI) & $\geq .90$ \\
\hline T-Values & $>1.96$
\end{tabular}

Catatan. Sumber penjelasan singkat dari "Multivariate Data Analysis" ditulis oleh Hair, J. F., Tatham, R. L., dan Anderson, R. E., 2014.

\section{Hasil}

Berikut adalah hasil estimasi reliabilitas alat ukur CAAS yang telah diadaptasi pada penelitian ini. Menurut Kaplan dan Saccuzzo (2009), alat ukur dikatakan reliabel jika memiliki koefisien reliabilitas Alpha Cronbach sebesar $\geq .70$. Tabel 3 di bawah ini menunjukkan nilai Alpha Cronbach yang merupakan nilai reliabilitas dari penelitian ini:

\section{Tabel 3}

Reliabilitas Alat Ukur Career Adapt-Ability Scale

\begin{tabular}{lcc}
\hline \multicolumn{1}{c}{ Dimensi } & $n$ & Cronbach's $\alpha$ \\
\hline Concern & 6 & .799 \\
Control & 6 & .746 \\
Curiosity & 6 & .798 \\
Confidence & 6 & .815 \\
$N$ & 24 & .923 \\
\hline
\end{tabular}

Selain itu, semakin besar nilai corrected item-total correlation pada masing-masing butir maka semakin tinggi daya beda butir. Artinya, masing-masing butir mengukur hal yang berbeda. Jika nilai corrected item-total correlation berada $<.3$ maka butir tersebut mengukur hal yang sama dengan butir lain sehingga perlu diperbaiki atau dihapus (Kaplan \& Saccuzzo, 2009). Tabel 4 di bawah ini menunjukkan hasil analisis butir berdasarkan nilai corrected item-total correlation: 


\section{Tabel 4}

Daya Beda Item

\begin{tabular}{|c|c|c|}
\hline \multicolumn{2}{|l|}{ Item Career Adapt-Ability } & \multirow[t]{2}{*}{$\begin{array}{l}\text { Cronbach's Alpha } \\
\text { if Item Deleted }\end{array}$} \\
\hline Dimensi Concern & & \\
\hline 1. Memikirkan gambaran masa depan saya kelak & .585 & .919 \\
\hline $\begin{array}{l}\text { 2. Mengetahui bahwa pilihan karier yang dibuat saat ini } \\
\text { menentukan masa depan saya }\end{array}$ & .488 & .921 \\
\hline $\begin{array}{l}\text { 3. Melakukan berbagai upaya untuk mempersiapkan } \\
\text { masa depan saya }\end{array}$ & .620 & .919 \\
\hline $\begin{array}{l}\text { 4. Mengetahui apa saja pilihan pekerjaan dan pilihan } \\
\text { dalam melanjutkan pendidikan yang harus saya buat }\end{array}$ & .446 & .922 \\
\hline 5. Merencanakan cara untuk mencapai cita-cita saya & .622 & .919 \\
\hline 6. Memperhatikan karier saya & .555 & .920 \\
\hline \multicolumn{3}{|l|}{ Dimensi Control } \\
\hline 1. Selalu bersemangat dalam menggapai karier saya & .574 & .920 \\
\hline 2. Membuat keputusan karier sendiri & .563 & .920 \\
\hline $\begin{array}{l}\text { 3. Bertanggung jawab atas tindakan yang saya } \\
\text { lakukan }\end{array}$ & .526 & .920 \\
\hline $\begin{array}{l}\text { 4. Berpegang teguh pada pilihan karier yang sudah } \\
\text { saya pilih }\end{array}$ & .541 & .920 \\
\hline 5. Mengandalkan diri sendiri & .310 & .924 \\
\hline 6. Melakukan hal yang mendukung tujuan karier saya & .629 & .919 \\
\hline \multicolumn{3}{|l|}{ Dimensi Curiosity } \\
\hline $\begin{array}{l}\text { 1. Mencari tahu lebih banyak informasi dari orang } \\
\text { orang sekitar saya }\end{array}$ & .492 & .921 \\
\hline 2. Mencari kesempatan untuk mengembangkan diri & .733 & .917 \\
\hline $\begin{array}{l}\text { 3. Mencari tahu lebih mendalam mengenai pilihan } \\
\text { karier dan pilihan pendidikan yang ada sebelum } \\
\text { mengambil keputusan }\end{array}$ & .595 & .919 \\
\hline $\begin{array}{l}\text { 4. Memperhatikan orang lain dalam melakukan } \\
\text { sesuatu dengan cara-cara yang berbeda dari kita }\end{array}$ & .456 & .922 \\
\hline $\begin{array}{l}\text { 5. Mencari tahu lebih dalam mengenai hal-hal yang } \\
\text { ingin saya ketahui }\end{array}$ & .586 & .919 \\
\hline $\begin{array}{l}\text { 6. Senantiasa tergerak untuk mencari kesempatan } \\
\text { kesempatan baru }\end{array}$ & .657 & .918 \\
\hline \multicolumn{3}{|l|}{ Dimensi Confidence } \\
\hline $\begin{array}{l}\text { 1. Mengerjakan tugas dengan tepat dan tidak } \\
\text { membuang-buang waktu, tenaga, maupun biaya }\end{array}$ & .427 & .922 \\
\hline 2. Memastikan pekerjaan dilakukan sebaik mungkin & .628 & .919 \\
\hline 3. Mempelajari keterampilan-keterampilan baru & .606 & .919 \\
\hline $\begin{array}{l}\text { 4. Bekerja semaksimal mungkin sesuai dengan } \\
\text { kemampuan saya }\end{array}$ & .574 & .920 \\
\hline 5. Mengatasi berbagai hambatan dalam hidup saya & .613 & .919 \\
\hline $\begin{array}{l}\text { 6. Menyelesaikan berbagai permasalahan dalam hidup } \\
\text { saya }\end{array}$ & .516 & .921 \\
\hline
\end{tabular}


Setelah dilakukan estimasi reliabilitas, kemudian dilakukan confirmatory factor analysis terhadap data dengan bantuan program LISREL. Berikut adalah hasil analisis berdasarkan kriteria goodness of fit:

\section{Tabel 5}

Nilai Kriteria Model Career Adaptability

\begin{tabular}{lcc}
\hline \multicolumn{1}{c}{ Estimasi } & Kriteria & Hasil \\
\hline Minimum Fit Function Chi-Square & $p>.05$ & .018 \\
\hline Root Mean Square Error of Approximation (RMSEA) & $<.08$ & .041 \\
\hline Goodness of Fit Index (GFI) & $\geq .90$ & .84 \\
\hline Normed Fit Index (NFI) & $\geq .90$ & .98 \\
\hline Comparative Fit Index (CFI) & $\geq .90$ & .98 \\
\hline Relative Fit Index (RFI) & $\geq .90$ & .91 \\
\hline
\end{tabular}

Kemudian, untuk melihat nilai signifikansi masing-masing butir dalam menggambarkan dimensi career adaptability diperlukan evaluasi terhadap nilai $t$. Nilai $t>1.96$ menunjukkan bahwa butir signifikan dalam mengukur variabel latennya (Hair et al., 2014). Selain itu, diperlukan juga evaluasi terhadap nilai loading factor untuk melihat sejauh mana hubungan antara masing-masing butir dengan dimensi career adaptability. Menurut Hair et al (2014) nilai loading factor diharapkan $>.50$ untuk menunjukkan hubungan yang cukup baik dengan variabel latennya. Nilai loading factor < .50 menunjukkan hubungan yang lemah dan perlu dilakukan perbaikan terhadap butir.

Berdasarkan hasil confirmatory factor analysis, ditemukan nilai $t$ seperti pada Gambar 1 di bawah ini: 


\section{Gambar 1}

Nilai T-Values Career Adapt-Ability Scale

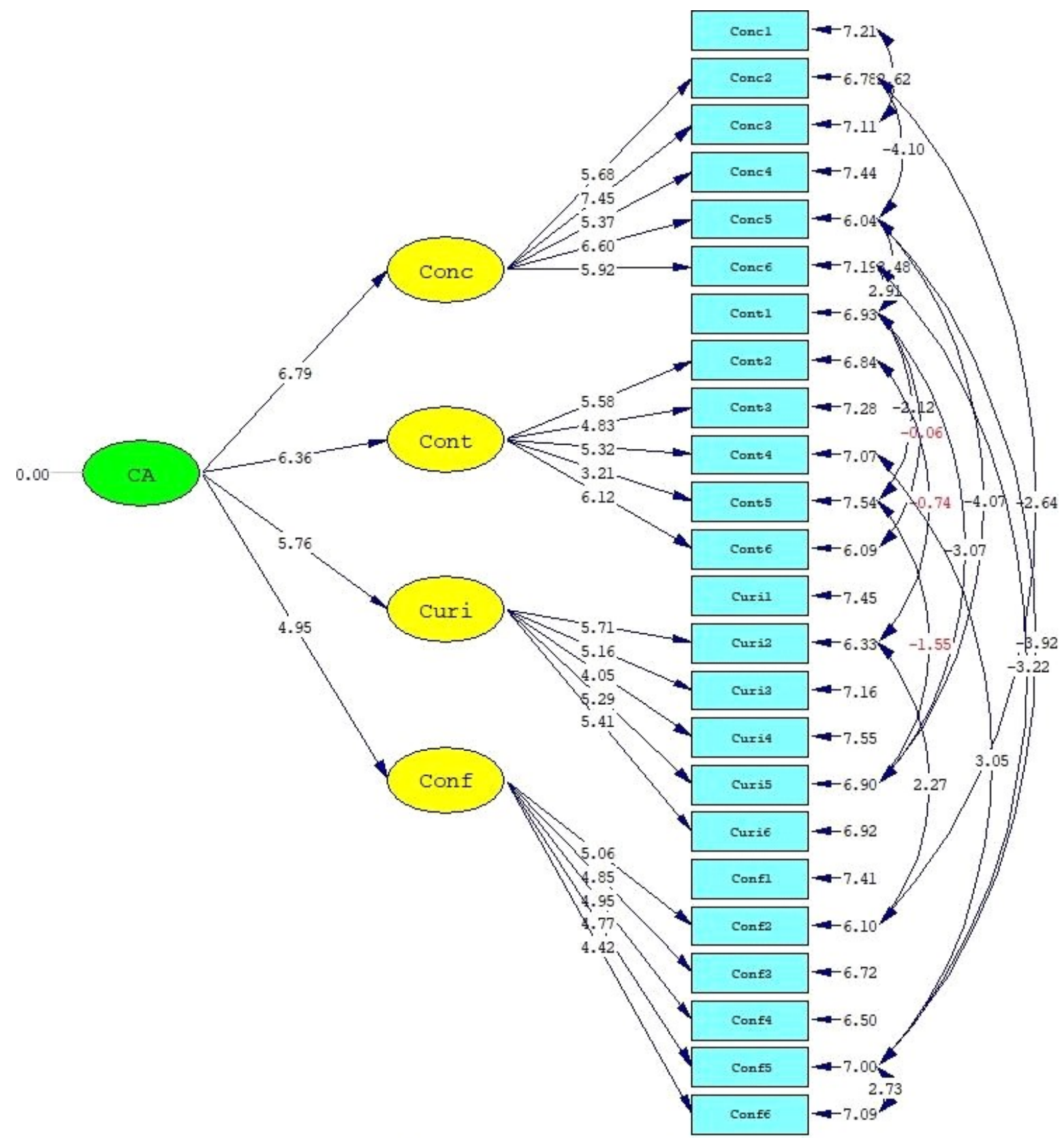

Chi-Square $=279.01, \mathrm{df}=232, \mathrm{P}$-value $=0.01873, \mathrm{RMSEA}=0.041$

Sedangkan, untuk nilai loading factor masing-masing butir terhadap dimensi career adaptability adalah sebagai berikut: 


\section{Gambar 2}

Nilai Loading Factor Career Adapt-Ability Scale

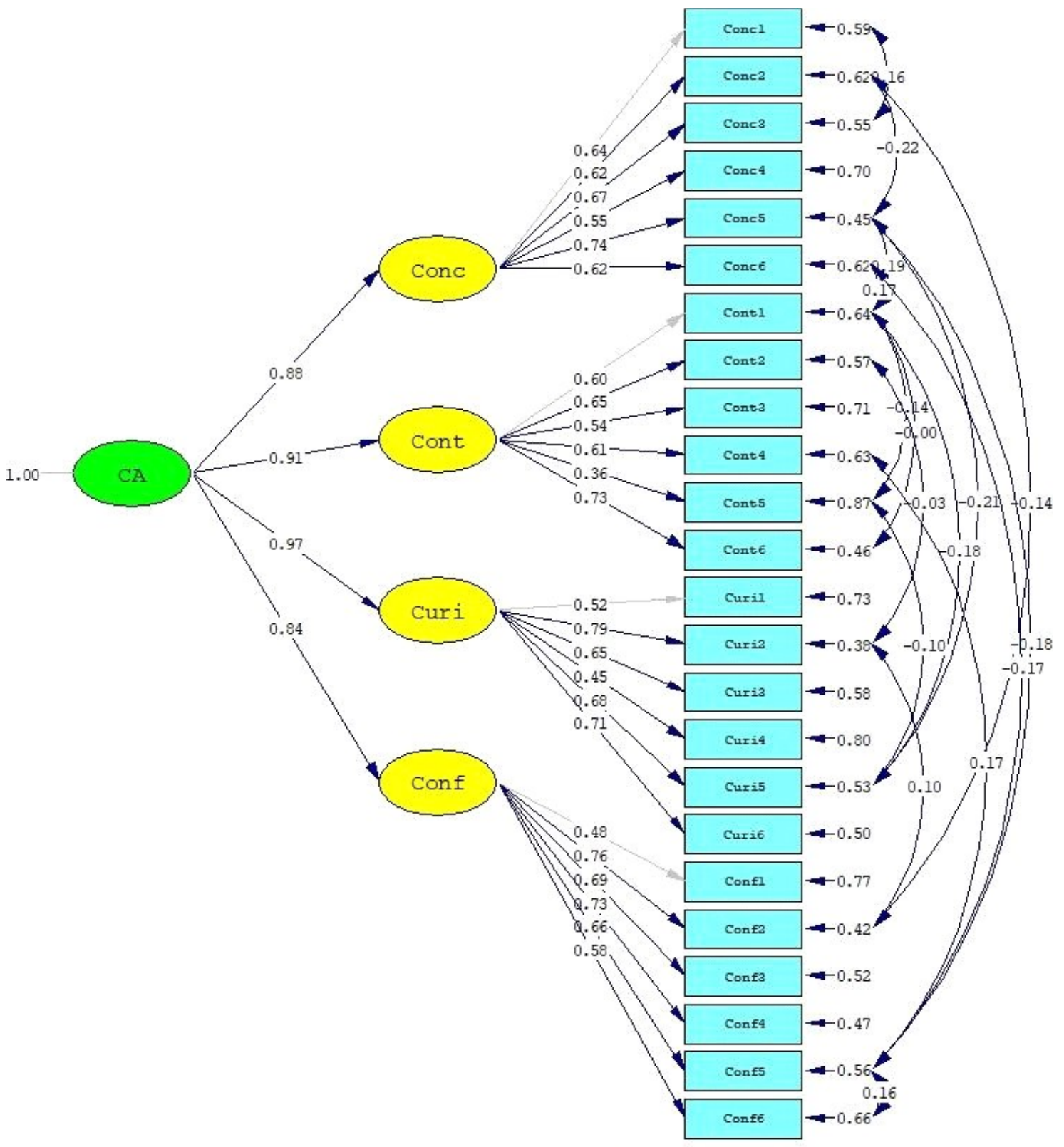

Chi-Square $=279.01, \mathrm{df}=232, \mathrm{P}$-value $=0.01873, \mathrm{RMSEA}=0.041$

\section{Pembahasan}

Estimasi reliabilitas yang telah dilakukan pada penelitian ini menunjukkan bahwa alat ukur CAAS memiliki reliabilitas yang baik. Menurut Kaplan dan Saccuzzo (2009), alat ukur dikatakan reliabel jika memiliki koefisien reliabilitas Alpha Cronbach sebesar $\geq .70$. Tabel
3 di atas menunjukkan 3 bahwa nilai reliabilitas masing-masing dimensi (partial reliability) dan keseluruhan alat ukur CAAS (composite reliability) menunjukkan angka $>.700$.

Selanjutnya, analisis butir dilakukan dengan melihat nilai corrected-item total correlation. Analisis ini dilakukan untuk melihat 
konsistensi antara skor butir dengan skor secara keseluruhan. Konsistensi ini dilihat dari besarnya nilai corrected-item total correlation $>$.30. Menurut Kaplan \& Saccuzzo (2009), semakin besar nilai corrected item-total correlation maka semakin tinggi daya beda butir. Artinya, masing-masing butir mengukur hal yang berbeda. Jika nilai corrected item-total correlation berada $<.30$ maka butir tersebut mengukur hal yang sama dengan butir lain sehingga perlu diperbaiki atau dihapus. Tabel 4 menunjukkan hasil analisis butir berdasarkan daya beda butir menggunakan nilai corrected item-total correlation yang bergerak dari .310 - .733. Seluruh butir berada di atas kriteria minimum yaitu $>.30$, sehingga dapat disimpulkan bahwa butir yang terdapat pada kuesioner memiliki daya pembeda yang baik.

Pengujian bukti validitas konstruk dilakukan melalui CFA. Seperti yang terlihat pada Tabel 5, terdapat kriteria goodness of fit terpenuhi maupun yang belum terpenuhi. Dalam hal ini, nilai chi square (.081) dan GFI (.84) belum memenuhi nilai kriteria. Hal ini dipengaruhi oleh jumlah sampel pada penelitian (Hair et al, 2014). Penelitian Doll et al (1994) juga menyatakan bahwa, sekalipun nilai chi square menggambarkan keseluruhan model fit dan sangat bergantung dengan jumlah sampel. Hal ini sejalan dengan populasi penelitian ini yang terbatas pada kelompok tertentu (salah satu sekolah di Kab. Sumedang, Jawa Barat, Indonesia) dengan jumlah yang masih tergolong sedikit untuk merepresentasikan kelompok yang lebih luas. Oleh karena itu, parameter yang lain dibutuhkan untuk melihat kesesuaian antara model penelitian dengan model teori aslinya. Pada Tabel 5, parameter RMSEA, NFI, CFI, dan RFI sudah memenuhi kriteria, yaitu > .90. Walau nilai GFI (.84) kurang memenuhi kriteria, masih termasuk ke dalam reasonable fit dan dapat diterima (Baumgartner \& Homburg, 1996; Doll et al., 1994). Dengan demikian, dapat disimpulkan bahwa model data yang ada sesuai dengan model teori career adaptability.

Untuk melihat nilai signifikansi masingmasing butir dalam menggambarkan dimensi career adaptability diperlukan evalusi terhadap nilai $t$ masing-masing butir. Berdasarkan hasil analisis yang ditunjukkan melalui Gambar 1, nilai $t$ bergerak dari $3.21-7.45$. Nilai $t>1.96$ menunjukkan bahwa butir signifikan dalam mengukur variabel latennya (Hair et al., 2014). Seluruh butir menunjukkan bahwa seluruh butir signifikan dalam menggambarkan masing-masing dimensi career adaptability. Selain itu, dilakukan evaluasi terhadap nilai loading factor yang ditunjukkan melalui Gambar 2. Berdasarkan nilai loading factor tersebut, seluruh butir pada dimensi concern memiliki hubungan yang cukup kuat dengan dimensinya. Artinya, butir-butir pada dimensi concern signifikan dalam mengukur dimensi concern dan cukup kuat dalam merepresentasikan dimensinya. Pada dimensi control, curiosity, dan confidence, terdapat masing-masing 1 butir yang menunjukkan hubungan lemah dengan 
dimensinya. Butir-butir ini dipandang kurang kuat dalam menggambarkan atau merepresentasikan masing-masing dimensinya. Walaupun demikian, butir-butir ini masih dapat digunakan untuk menggambarkan atau merepresentasikan masing-masing dimensi control, curiosity, dan confidence karena memiliki signifikasi yang cukup baik. Sekalipun butir-butir ini cukup lemah, namun dipandang masih signifikan dalam merepresentasikan masing-masing dimensinya.

Implikasi dari hasil analisis keseluruhan alat ukur CFA pada penelitian ini menunjukkan bahwa CASS dapat digunakan untuk mengukur career adaptability pada siswa sekolah. Setiap butir yang ada pada dimensi concern, control, curiosity, \& confidence dapat merepresentasikan dimensinya sesuai dengan sample yang ada pada penelitian, sehingga berimplikasi bahwa CASS dapat memperkirakan career adaptability. Kemudian, temuan dari penelitian ini juga bisa saja berimplikasi pada adanya perkiraan kemampuan adaptasi karier siswa terhadap kesiapannya meniti karier di masa depan, namun hal ini masih membutuhkan penelitian lebih lanjut. Diharapkan penelitian selanjutnya untuk menelaah CASS secara mendalam dari berbagai konteks.

\section{Simpulan}

Alat ukur CAAS telah teruji dapat mengukur career adaptability berdasarkan konsep yang dikemukakan oleh Savickas. Alat ukur ini memiliki reliabilitas yang baik sehingga alat ukur ini dapat diandalkan untuk mengukur career adaptability walaupun diukur pada responden yang berbeda dan pada waktu yang berbeda pula. Alat ukur ini juga terbukti mampu mengukur career adaptability sesuai dengan model teorinya dan masing-masing butir dalam alat ukur ini signifikan dalam mengukur masingmasing dimensi dari career adaptability.

\section{Saran}

Sebagai saran untuk penelitian berikutnya, diperlukan pengambilan data pada sampel yang lebih banyak dan populasi lain serta pengumpulan bukti validitas yang lain untuk menyempurnakan bukti validitas terhadap alat ukur Career Adapt-Ability Scale yang telah diadaptasi ke dalam bahasa Indonesia ini.

\section{Referensi}

Baumgartner, H., \& Homburg, C. (1996). Application of structural equation modeling in marketing and consumer research: A review. International Journal of Research in Marketing, 13, 139-161. file:///C:/Users/JODIE/ Dropbox/KULIAH/International Journal of Research in Marketing Volume 13 issue 21996 [doi 10.1016_01678116(95)00038-0] Hans Baumgartner

Christensen, L. B., Johnson, R. B., \& Turner, L. A. (2015). Research methods, design, and analysis (12th ed.). Pearson Education Limited. file:///C:/Users/JODIE/ Downloads/Larry B. Christensen, R. Burke Johnson, Lisa A. Turner - Research Methods, Design, and Analysis-Pearson (2014).pdf

Doll, W. J., Xia, W., \& Torkzadeh, G. (1994). A confirmatory factor analysis of the enduser computing satisfaction instrument. MIS Quarterly, 18(4), 453-461. file:/// 
C:/Users/JODIE/Dropbox/KULIAH/MIS Quarterly Volume 18 issue 41994 [doi 10.2307_249524] William J. Doll, Weidong Xia and Gholamreza Torkzadeh - A Confirmatory Factor Analysis of the End-User Computing Satisfaction Instrument.pdf

Goodwin, J. (2010). Research in psychology (6th ed.). John Wiley \& Sons. file:///C:/ Users/JODIE/Downloads/C. James Goodwin - Research In Psychology_ Methods and Design -Wiley (2009).pdf

Hair, J. F., Black, W. C., Babin, B. J., \& Anderson, R. E. (2014). Multivariate data analysis (7th ed.). Pearson Education Limited. file:/ //C:/Users/JODIE/Dropbox/KULIAH/ Jr., William C. Black, Barry J. Ba Joseph F. Hair - Multivariate Data Analysis-Pearson Education Limited (2013).pdf

Hamtiaux, A., Houssemand, C., \& Vrignaud, P. (2013). Individual and career adaptability: Comparing models and measures. Journal of Vocational Behavior, 83(2), 130-141. https:// doi.org/10.1016/j.jvb.2013.03.006

Kaplan, R. M., \& Saccuzzo, D. P. (2009). Psychological testing: Principles, applications, and issues (7th ed.). Wadsworth Cengage Learning. file:///C:/ Users/JODIE/Downloads/Robert M. Kaplan, Dennis P. Saccuzzo Psychological Testing_ Principles, Applications, and Issues (2008, Wadsworth Publishing) - libgen.lc.pdf

Koufteros, X., \& Marcoulides, G. A. (2006). Product development practices and performance: A structural equation modeling-based multi-group analysis. International Journal of Production Economics, 103(1), 286-307. https:// doi.org/10.1016/j.ijpe.2005.08.004

Liman, A. S. (2018). Gambaran career adaptability pada siswa SMK
Padjadjaran Jatinangor [Universitas Padjadjaran]. https://lib.unpad.ac.id/ index.php? node $=$ Fakultas + Psikologi $\& \mathrm{p}=$ show_detail\&id=14086\&keywords=

Ployhart, R., \& Bliese, P. (2006). Individual adaptability (I-ADAPT) theory: Conceptualizing the antecedents, consequences, and measurement of individual differences in adaptability. In Understanding Adaptability: A Prerequisite for Effective Performance within Complex Environments (pp. 339). Elsevier. https://doi.org/10.1016/ S1479-3601(05)06001-7

Savickas, M. L., \& Porfeli, E. J. (2005). The theory and practice of career construction. In S. D. Brown \& R. W. Lent (Eds.), Career Development and Counseling. John Wiley \& Sons. file:/// C:/Users/JODIE/Dropbox/KULIAH/ Mapro Unpad 2016/SEMESTER 3/ TESIS/Jurnal Tesis/Career Adaptability/ B00KS - SD Brown, RW Lent (2005) Career Development and Counseling Putting Theory and Research to Work.pdf

Savickas, M. L., \& Porfeli, E. J. (2012). Career adapt-abilities scale: Construction, reliability, and measurement equivalence across 13 countries. Journal of Vocational Behavior, 80(3), 661-673. h ttp s: / / doi.org/10.1016/ j.jvb.2012.01.011

Sulistiani, W., Suminar, D. R., \& Hendriani, W. (2018). The career adapt-abilities scaleIndonesian form: Psychometic. The 4th International Conference on Education, 4(2), 1-9. https://doi.org/10.17501/ 24246700.2018.4201

Received 18 September 2020 Revised 30 April 2021 Accepted 31 July 2021 
